
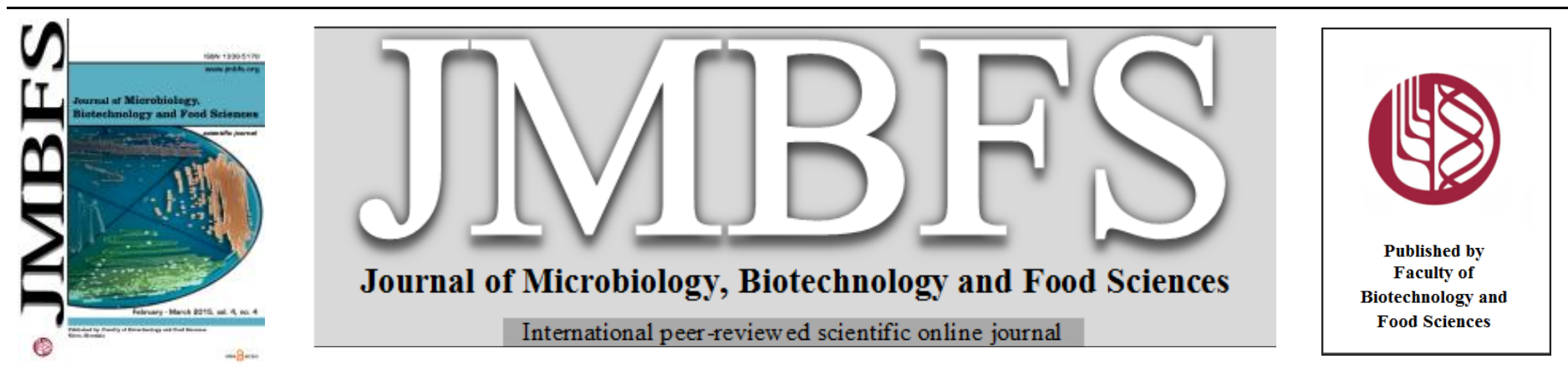

\title{
ANTIBACTERIAL AND BIOCHEMICAL EFFECTS OF ETHANOL LEAF EXTRACT OF SENNA HIRSUTA MILL USING ANIMAL MODEL-MICE
}

\author{
Fred Coolborn Akharaiyi ${ }^{1}$, Bolatito Boboye ${ }^{2}$, Victoria Omolara Akpambang ${ }^{3}$ \\ Address(es): Mr. Fred Coolborn Akharaiyi, \\ ${ }^{1}$ Biological Sciences Department, Afe Babalola University, P. M. B. 5454, Ado Ekiti, Ekiti State, Nigeria. \\ ${ }^{2}$ Microbiology Department, Federal University of Technology, P. M. B. 704, Akure, Ondo State, Nigeria. \\ ${ }^{3}$ Chemistry Department, Federal University of Technology, P. M. B. 704, Akure, Ondo State, Nigeria.
}

*Corresponding author: akharaiyifc@gmail.com

doi: 10.15414/jmbfs.2015.4.4.292-296

ARTICLE INFO

Received 24. 10. 2014

Revised 14. 11. 2014

Accepted 25. 11. 2014

Published 1. 2. 2015

Regular article

open $\odot$ access

\section{ABSTRACT}

This study was carried out to investigate the in-vitro and in-vivo antibacterial and biochemical activities of 50,100 and $200 \mathrm{mg}^{-\mathrm{mL}^{-1}}$ concentrations of ethanol leaf extract of Senna hirsuta (hairy senna) against seven human pathogenic bacteria species namely: Pseudomonas aeruginosa, Escherichia coli, Klebsiella pneumoniae, Staphylococcus aureus, Enterococcus faecium, Bacillus cereus and Salmonella typhi. The in-vitro bioassay revealed the leaf extracts of valuable antibacterial activity where zones of inhibition ranging from $12.1 \mathrm{~mm}$ to $39.1 \mathrm{~mm}$ were observed on the test bacteria species. Among the test bacteria, K. pneumoniae was the most inhibited and S. typhi the least inhibited. On mice infection with the bacteria species for three days, decrease in weight of mice was observed. The invivo therapeutic use of the extracts in mice infected with the bacteria pathogens resulted to weight gain of the mice and other physiological changes that indicated health improvement of the mice and was also of hepatoprotective potential. The in-vivo antioxidant assay exhibited satisfactory therapeutic effects where improvement in aspartate aminotransferase (AST), alanine aminotransferase (ALT), and alkaline phosphatase (ALP) status of mice was observed on comparing results of the positive and negative controls.

Keywords: Plant extracts, activities, antibacterial, albino mice, biochemical

\section{INTRODUCTION}

Nature has been a source of medicinal agents for thousands of years and an impressive number of modern drugs have been isolated from natural sources (Cragg and Newman, 2001) where many are based on their use in traditional medicine. Antimicrobial drugs have caused a dramatic change not only of the treatment of infectious diseases but of a fate of mankind. Antimicrobial chemotherapy made remarkable advances, resulting in the overly optimistic view that infectious diseases would be conquered in the near future. Plant compounds are of interest as a source of safer or more effective substitutes than synthetically produced antimicrobial agents. Higher plants as sources of medicinal compounds have continued to play a dominant role in the maintenance of human health since ancient times (Ahmed et al., 1998). Over 50\% of all modern clinical drugs are of natural product origin and natural clinical products play an important role in drug development programme in the pharmaceutical industries (Khan et al., 2009).

The use of natural medicine is a popular practice in Nigeria hence diverse species of plants that serves as antimicrobial agents. In Nigeria, more than 80 medicinal plants are used in different combinations in the preparations of herbal formulations effective in treatment of several diseases of microbial and non microbial origins. Despite this, only a small proportion of hepatoprotective plants as well as formulations used in traditional medicine are pharmacologically evaluated for their safety and efficacy.

Several Bacteria species have been reported to cause diseases in man which need urgent attention to avoid death. Some bacteria species such as $S$. dysenteriae, $P$. aeruginosa, E. coli and $K$. pneumoniae among others have been reported to be associated with nosocomial and community acquired infections. If their colonization occurs in critical body organs such as the lungs, the urinary tract, and kidneys, the results can be fatal and may result to oxidative stress cascade by free radicals which cause damage in cell structures that include proteins and DNA along with lipid peroxidation (Tiwari, 2001; Nagmoti et al., 2011). Novel traditional technologies such as infusion, decoction and concoction with water solutions to high polar solvents such as ethanol, and methanol extractive methods have been used to improve herbal therapy in traditional medicine. Practices in using one or more of the mentioned methods have helped in providing lasting solutions for prevention and curing of deleterious diseases in the traditional way.
The agitation is that though majority of these plants extracts have been found useful in antibacterial, antifungal, antimicrobial, anti-tumur, anti inflammatory, antihypertensive and other deleterious diseases, emphases is however not laid on any negative effect on human organs such as liver, kidney intestine etc.

Many species of Senna have been used medicinally, they have a rich history in natural medicine and they have been known since the $9^{\text {th }}$ or $10^{\text {th }}$ century as purgative and laxatives. Seeds and leaves of $S$. hirsuta are substituted for coffee. $S$. hirsuta has a unique effect for Senna in that it is used to treat poisoning caused by food, water, alcohol and inhalation. As a precaution, no Senna species should be taken by women who are pregnant, breast-feeding or in their menstrual period (Monkheang et al., 2011). According to (Dennis, 1988). Senna bark and oil extract are used for flavouring purposes and in soaps, candy and perfumery. The leaf is the ubiquitously used part because of its utilization and therapeutic values. But generally, the leaf, flower, root and seed are used in herbal medicine all over the world. Their actions include, analgesic, antibacterial, antifugal, antihepatotoxic, anti inflammatory, antiseptic, antiparasitic, diaphoretic emmenagogue, laxative, vermifuge, purgative, stomachic, febrifuge and other reproductive problems arbortifacient (Burkill, 1994; Dennis, 1988). Economically, the roasted seeds can be used to substitute coffee, which is well used throughout the range of the plant's dispersal. The plant is potent for curing herpes, chest pains and elephantiasis (Burkill, 1994). Though little information is available on its antimicrobial effect, there is no report in the literature on the protective effect of formulated Senna hirsuta extract against pathogenic bacterial infection induced liver injury. The aim of this study is to evaluate $S$. hirsuta ethanol leaf extract for effectiveness in in-vitro and in-vivo inhibition of the growth of some selected pathogenic bacteria, its effect in biochemical and histological indices in mice.

\section{MATERIAL AND METHODS}

\section{Collection of plant samples and extracts preparations}

Healthy looking leaves of S. hirsuta was collected from forest in Akure, Ondo State, Nigeria and identified in Department of Forestry and Wood Technology, Federal University of Technology, Akure, Nigeria. The voucher number of the 
plant AF 1506 was deposited in the herbarium. The plants parts were air dried for 3 weeks at room temperature of $25 \pm 2^{\circ} \mathrm{C}$ on side bench in the laboratory and then ground to powder with a mechanical grinder.

\section{Test bacteria isolates}

Common clinical bacteria species were obtained from Microbiology Department, Federal University of Technology, Akure. The bacteria includes: Pseudomonas aeruginosa, Enterococcus faecium, Bacillus cereus, Salmonella typhi, Escherichia coli, Klebsiella pneumoniae and Staphylococcus aureus. These bacteria isolates were identified by cultural characteristics such as shape, colour, seize, elevation, gram staining and biochemical tests such as catalase, coagulase, oxidase, motility and carbohydrate utilization as described by Cheesbrough (2003). Identification of the bacterial isolates was done by comparing their characteristics with those of known taxa as described in Bergey's manual for Determinative Bacteriology according to Holt et al. (1994).

\section{Bioassay of the plant extract}

Antibacterial activity of the extracts was assayed using agar diffusion technique The crude ethanol leaf extracts was assayed against the test bacteria species where $0.5 \mathrm{~mL}$ of $24 \mathrm{~h}$ broth culture $\left(1.0 \times 10^{6}\right.$ cell. $\left.\mathrm{mL}^{-1}\right)$ was poured plated with Mueller Hinton agar and allowed to stand for about $2 \mathrm{~h}$. A cork borer of $1 \mathrm{~mm}$ size was used to bore wells on the bacterial seeded petri dishes. Prepared extract concentrations of 50,100, $200 \mathrm{mg} . \mathrm{mL}^{-1}$ were carefully introduced into the wells The plates were labeled and incubated at $37^{\circ} \mathrm{C}$ for $24 \mathrm{~h}$. After incubation, clear zones of inhibition around the well indicate the sensitivity rate of the test bacteria to each of the extract concentrations. Streptomycin at $20 \mathrm{mg}^{\mathrm{mL}} \mathrm{m}^{-1}$ was used as control. Diameters of inhibition zones created were measured and taken as index of degree of sensitivity.

\section{Experimental animals}

Thirty two apparently healthy Swiss albino mice of between 23-35 g were used The animals were contained in a cage and maintained under standard laboratory conditions. They were given rodent pellets (Vital feeds) and water ad libitum. They were acclimatized for 2 weeks and were fasted over night with free access to water prior the experiments. The animals were conducted in compliance with NIH Guide for Care and Use of Laboratory Animals.

\section{Test bacteria inoculation into mice and treatment with extract}

The mice were weighed and randomized into 8 groups of 4 animals each. Group one served as negative control and was allowed to normal feed and water. $1 \mathrm{~mL}$ of $10^{3} \mathrm{Cfu} . \mathrm{mL}^{-1}$ of washed $E$. coli cells were administered to each mouse in group two orally with the aid of a wash bottle whose dispenser was directly laid on the mice throat in a single dose per day for $72 \mathrm{~h}$. This was repeated with $K$ pneumoniae in group three, $S$. aureus in group four, E. faecium in group five, $B$ cereus in group six, $S$. typhi in group seven and $P$. aeruginosa in group eight. The animals were observed continuously for any gross change in behavioral, neurological, autonomic profiles and mortality in each group. The test organisms were confirmed in the mice faeces by plating $1 \mathrm{~mL}$ each of serially diluted samples on MacConkey agar, Eosin methylene blue agar, Mannitol salt agar, Salmonella Shigella agar and nutrient agar. Based on colonial colour and cultura characteristics on the selective media, resultant colonies were purified and identified for confirmation of their presence in faeces of the mice each organism was fed. On noticing symptoms of illness in the mice, one mouse in each group was isolated and left untreated thus serving as positive control while the remaining three were administered with 50,100 and $200 \mathrm{mg} \cdot \mathrm{kg}^{\text {bw }}$ of extract in a single dose for three days.

\section{Preparation of serum and liver homogenate}

The mice were made unconscious in a jar containing cotton wool soaked in chloroform. Thereafter, their jugular veins were cut; head held downwards and allowed to bleed into a clean, dry centrifuge tubes. The tubes were left at room temperature for $10 \mathrm{~min}$ and centrifuged at $33.5 \mathrm{x} \mathrm{g}$ for $15 \mathrm{~min}$. The sera were aspirated using Pasteur pipettes into clean, dry, sample bottles and stored at $-20^{\circ}$ $\mathrm{C}$ for $24 \mathrm{~h}$. Immediately after collection of blood, the mice were dissected to remove liver which were transferred into $0.25 \mathrm{M}$ sucrose solution. The liver was blotted with tissue paper, cut very thinly with sterile scalpel blade and homogenized in ice-cold 0.25M sucrose solution (1:5 v/v) (Akanji et al., 1993). The homogenates were further centrifuged at $1340 \times \mathrm{g}$ for $15 \mathrm{~min}$ to obtain supernatant, which was then carefully collected into sample bottle and used for the various biochemical assays.

\section{Aspartate aminotransferase Activity assay}

The method of (Bergmeyer et al., 1986a) was adopted with little modifications Briefly, aspartate aminotransferase (AST) activity was measured by monitoring the following information of oxaloacetate hydrazone with 2, 4dinitrophenylhydrazine. $0.5 \mathrm{~mL}$ each of AST substrate phosphate buffer was pipette into sample blank (B) and sample test (T) test tubes respectively. $0.1 \mathrm{~mL}$ serum sample was added to the sample test $(\mathrm{T})$ only and mixed immediately; and incubated in a water bath for 30 minutes at $37^{\circ} \mathrm{C}$. After incubation, $0.5 \mathrm{~mL}$ of 2,4 dinitrophenyldydrazine each was added to both sample tubes. Also, $0.1 \mathrm{~mL}$ of the sample was added to sample blank (B) only. The medium was mixed and allowed to stand for 20 minutes at $25^{\circ} \mathrm{C}$. Finally, $5.0 \mathrm{~mL}$ of $(\mathrm{NaOH})$ was added to both sample tubes, mixed thoroughly and absorbance of the test sample was read at a wavelength of $550 \mathrm{~nm}$ against sample blank after 5 minutes.

\section{Alanine aminotransferase activity assay}

The method of (Bergmeyer et al., 1986b) was also adopted. Briefly, alanine aminotransferase (ALT) was measured by monitoring the concentration of pyruvate hydrazone formed with 2,4-dinitrophenylhydrazine. $0.5 \mathrm{~mL}$ each of ALT substrate phosphate buffer was pipette into two sets of test tubes labelled B (sample blank) and $\mathrm{T}$ (sample test) respectively. $0.1 \mathrm{~mL}$ was added to sample test (T) only, mixed properly and incubated for 30 minutes in a water bath regulated at $37^{\circ} \mathrm{C}$. After incubation, $0.5 \mathrm{~mL}$ each of 2,4-dinitrophenylhydrazine was added to both tubes. Also, $0.1 \mathrm{~mL}$ of serum sample was added only to sample blank (B). The mixtures was shaken properly and allowed to stand for 20 minutes at $25^{\circ} \mathrm{C}$. Thereafter, $5.0 \mathrm{~mL}$ each $(\mathrm{NaOH})$ solution was added to both test tubes, mixed thoroughly and absorbance of the test sample was read against sample blank at a wavelength of $550 \mathrm{~nm}$ after 5 minutes.

\section{Assay of Alkaline Phosphatase Activity}

This method was based on the principle that serum alkaline phosphatase hydrolyses a colourless substrate of phenolphthalein monophosphate giving rise to phosphoric acid and phenolphthalein which at alkaline $\mathrm{pH}$ values turns into a pink colour that can be photometrically determined. $1.0 \mathrm{~mL}$ of distilled water was pipette into 2 sets of test tubes and labeled SA (sample) and ST (standard) respectively. Then one drop each of chromogenic substrate was added to the distilled water in the two sets of test tubes. The contents were mixed and incubated at $37^{\circ} \mathrm{C}$ for 20 minutes in a water bath. After which a standard solution of $0.1 \mathrm{~mL}$ was added only to the standard test tube (ST) while $0.1 \mathrm{~mL}$ serum sample was added to sample test tube (SA). The contents were mixed and incubated at $37^{\circ} \mathrm{C}$ for 20 minutes in a water bath. $5.0 \mathrm{~mL}$ each colour developer was added to both sets of test tubes. Absorbance of the sample against the blank (water) was read at a wavelength of $550 \mathrm{~nm}$. The activity of alkaline phosphatase in the serum was obtained from the formula (calculations) below:

$$
\frac{\text { ST O. D }}{\text { SA O.D }} * 30=\text { U. L of Alkaline phosphatase }
$$

Where: ST O.D = Standard Optical Density, SA O.D = Sample Optical Density.

\section{Histological examination of Liver}

Liver tissues were collected from the controls and extract treated after bacterial infection and washed in normal saline. The liver tissues were cut to small sizes and dehydrated with grades of ethanol starting from $50 \%$ - absolute. They were cleared in xylene, impregnated in paraffin wax, embedded and sectioned with a microtome at $4-7 \mu \mathrm{m}$. The sectioned tissues were stained with haematoxylin and eosin; mount with DPX and photographed. The photographed images were observed with microscope and interpreted according to the level of damages or protection potentials.

\section{Statistical Analysis}

The experimental data were expressed as mean \pm S.E.M (Standard error of mean). Data were analyzed by the analysis of variance (ANOVA).

\section{RESULTS}

\section{Bioassay of the plant extract}

The inhibitory activities of ethanol leaf extract concentrations of Senna hirsuta against seven bacteria species is shown in Figure 1. From the results obtained, $50 \mathrm{mg} \cdot \mathrm{mL}^{-1}$ extract concentration most inhibited $K$. pneumoniae with a zone of $23.1 \mathrm{~mm}$, followed by $P$. aeruginos $a$ with an inhibition of $22.8 \mathrm{~mm}, E$. coli with $20.3 \mathrm{~mm}$, while the least inhibition by this concentration was $17.5 \mathrm{~mm}$ on $S$. aureus. The $100 \mathrm{mg} \cdot \mathrm{mL}^{-1}$ concentration most inhibited $E$. coli with a zone of $27.4 \mathrm{~mm}$ followed by $K$. pneumoniae with inhibitory zone of $26.6 \mathrm{~mm}, S$. aureus with an inhibition of $26 \mathrm{~mm}$ and least inhibition of $25.3 \mathrm{~mm}$ was observed on $B$ cereus. The $200 \mathrm{mg} . \mathrm{mL}^{-1}$ extract concentration also most inhibited $E$. coli with a zone of $39.9 \mathrm{~mm}$, followed by $K$. pneumoniae which was inhibited with $39.1 \mathrm{~mm}$ zone. However, the least inhibition by this extract was observed on E. faecium with $25.9 \mathrm{~mm}$ zones of inhibition. The control drug (streptomycin) at 
concentration of $20 \mathrm{mg} \cdot \mathrm{mL}^{-1}$ most inhibited B. cereus with $16.2 \mathrm{~mm}$, followed by $P$. aeruginosa, E. faecium, and $S$. typhi with inhibition zones of $15 \mathrm{~mm}, 14 \mathrm{~mm}$ and $12.1 \mathrm{~mm}$ respectively. However, E. coli, K. pneumoniae and S. aureus were resistant to this drug at the employed concentration.

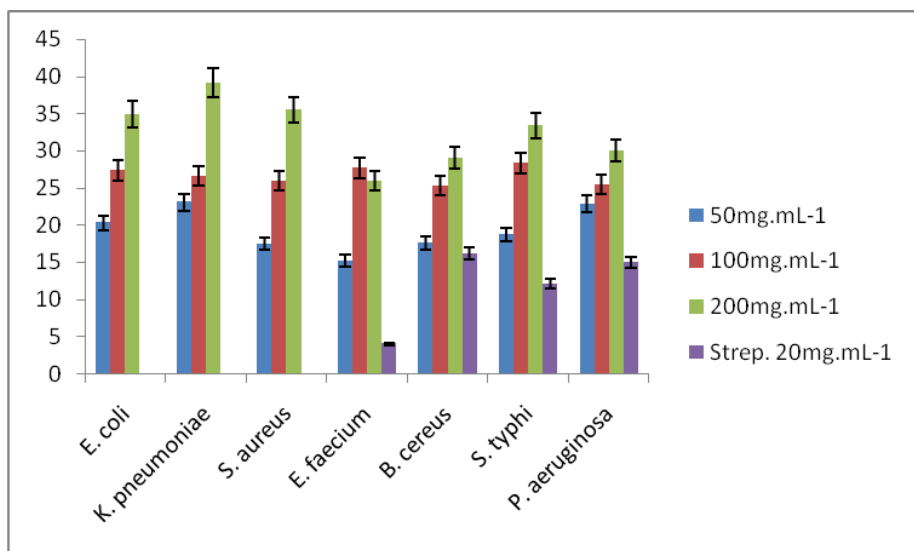

Figure 1 Zones of inhibition (mm) of ethanol leaf extract of Senna hirsuta on the bacteria isolates.

Figure 2 illustrates weight $(\mathrm{g})$ of mice before and after treatment with plant extract concentrations. Results showed it that the weight lost of mice infected with $E$. faecium decrease from $160 \mathrm{~g}$ to $152 \mathrm{~g}$. But after treatment with the plant extracts, subsequent increase in weight gain to $162 \mathrm{~g}$ was observed. Similarly, mice infected with B. cereus initially weighed $190 \mathrm{~g}$ and decreased to $182 \mathrm{~g}$. Meanwhile weight gain of $97 \%$ after treatment with the plant extracts was observed. Similar trend of decrease in weight was as well observed on the rest treatments after inoculated with bacteria pathogens and increase in weight after treatment with plant extracts.

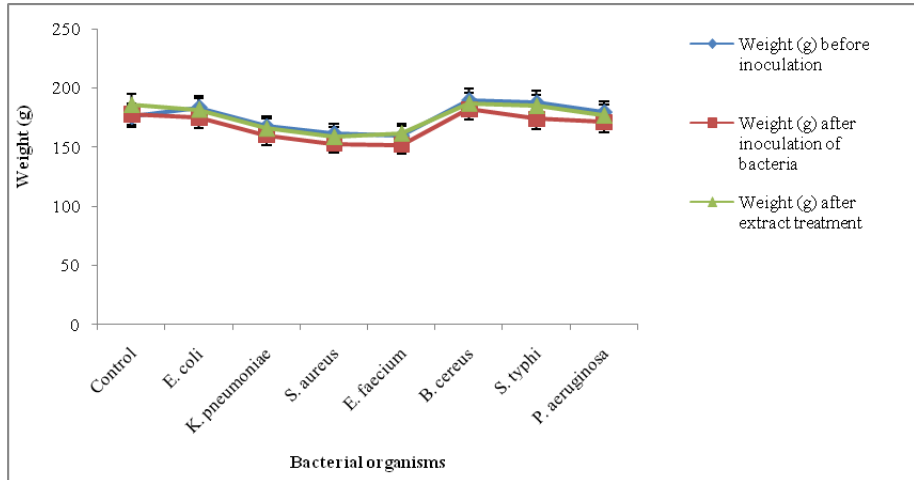

Figure 2 Weight of mice before, after inoculation and after extract treatment

\section{Biochemical Assay}

Figure 3 illustrates the biochemical enzyme makers of mice administered with the test bacteria species and co administered with extract concentrations. Increase in values were observed in aspartate aminotransferase (AST), alanine aminotransferase (ALT), and alkaline phosphatase (ALP) in the bacterial infected mice when compared with the negative control mice. In negative control mice, average values of AST, ALT, ALP are 55.53 $\pm 1.53,53.22 \pm 3.16$, and $198.18 \pm$ 3.74 (U.L) respectively. In groups of mice co administered with the different leaf extract concentrations after exposure to test bacteria, revealed close values in all the biochemical parameters. AST values obtained in $50 \mathrm{mg} . \mathrm{kg}^{\mathrm{bw}}, 100 \mathrm{mg} \cdot \mathrm{kg}^{\mathrm{bw}}$ and $200 \mathrm{mg} . \mathrm{kg}^{\mathrm{bw}}$ body weight leaf extract after inoculation of bacteria species are $55.53 \pm 1.53,62.79 \pm 2.56$ and $64.32 \pm 2.18$ (U.L) respectively while the ALT, values are $53.22 \pm 3.16,52.30 \pm 2.44$ and $50.14 \pm 2.10$ (U.L).

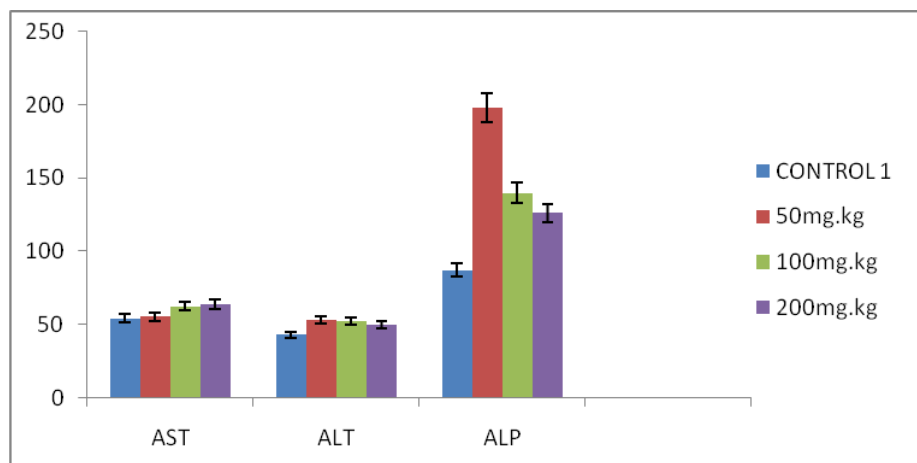

Figure 3 Effect of ethanol leaf extract of $S$. hirsuta on biochemical parameters in liver functions of albino mice.

\section{Histological examination of Liver}

Plates 1 shows the representative histopathological sections of liver tissue treated with $50-200 \mathrm{mg} \cdot \mathrm{mL}^{-1}$ of $S$. hirsuta ethanol leaf extract after infections with bacterial pathogens, where normal architectural structure, localized area of necrosis, hepatic necrosis and portal triad were observed as a sign of liver protection ability by the extracts concentration.

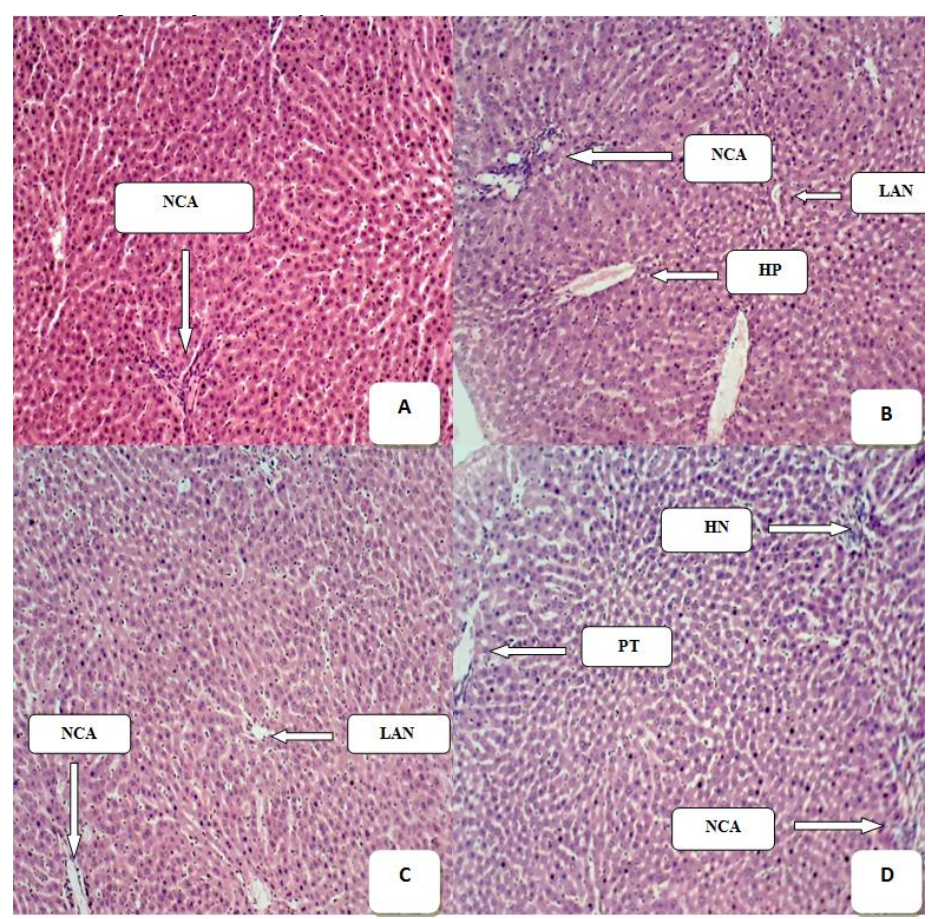

Plate 1 Histology of liver of mice untreated and treated with the various extract concentrations

(A): Representative of histopathological section of the Liver of Mice Fed With Normal Die and Water Showing Normal Cellular Architecture (NCA); (B): Representative of histopathological section of the Liver of Mice dosed with $50 \mathrm{mg} \cdot \mathrm{mL}^{-1}$ of $S$. hirsuta Showing Normal Cellular Architecture (NCA) hepatic necrosis (HP) and localized area of necrosis (LAN); (C): Representative of histopathological section of the Liver of Mice dosed with $100 \mathrm{mg} \cdot \mathrm{mL}^{-1}$ of $S$. hirsuta Showing Normal Cellular Architecture (NCA) and localized area of necrosis (LAN); (D): Representative of histopathological section of the Liver of Mice dosed with $200 \mathrm{mg}^{-\mathrm{mL}^{-1}}$ of S. hirsuta Showing Normal Cellular Architecture (NCA), Porta triad and hepatic necrosis.

\section{DISCUSSION}

The zones of inhibition produced by $S$. hirsuta extract on the test bacteria species were varied in the extract concentrations. The extracts showed more inhibitory activity at higher concentration of $200 \mathrm{mg} \cdot \mathrm{mL}^{-1}$ than at lower concentrations of 100 and $50 \mathrm{mg} \cdot \mathrm{mL}^{-1}$. The explicit antibacterial activity at higher extract concentration could be the contained inhibitory properties than in the lower extract concentrations. This is in agreement with the claim that antimicrobial agents function better at higher concentrations than at lower concentrations (Ajaiyeoba et al., 2003). The high evaluations demonstrated by $S$. hirsuta in antibacterial potency, invariably reflected in the hepatoprotective activities and this could be as a result of its phytochemical compounds able to inhibit bacteria and antioxidant potentials able to protect organs from reactive oxygen species (ROS) generated during bacterial infections. The spectrum of antibacterial activity demonstrated by the extracts as compared with control drug, explains the antibacterial potential of plant extracts in medicine. Therefore, plants evolutions 
in antimicrobial and hepatoprotective activity are important aspects in prediction of potential drugs or herbal preparations found effective in managing diseases most especially by those that accept their innumerable values for alternative therapy. Related studies of antimicrobial activity indicated that crude extracts containing flavonoids, triterpenes and steroids have showed significant activity against various strains of bacteria (Chattopadhyay et al., 2001). Inhibition of the bacteria species with black pepper extracts and ampicilin, a commercial antibiotic as control also has been reported by (Karsha and Lakshmi, 2010). It has been reported that antibiotics are not the only antibacterial agents and this study observed the effective potency of the studied plant extracts on the selected bacterial isolates than some of the highly rated antibiotics (reference drug) in disease cure and prevention. The quantity desired and methods of preparation of extracts to avoid contamination are of paramount importance in bio-assay quality. Contamination with heavy metals generally originates from polluted irrigation water, particulate air material; polluted air materials polluted soils and inappropriate storage conditions. Hence appreciable inhibitory results was obtained by the use of the plant extracts it is acknowledge that contamination was minimal which immensely could have helped in the valuable antibacterial potency observed. Plant extracts are natural products hence are gifts from Mother Nature and ordinarilly are suposed to be disease-free. Full range of plants have dexhibited nutritional supplements, phytochemicals and provitamins that help in sustaining good health and fighting diseases and are now being described as functional foods, nutriceuticals, and nutraceuticals (Loganayaki and Manian, 2010). Many herbals are on the market to support health, relieve symptoms and cure diseases but most of these products lack scientific pharmacological validation (Mohamed et al., 2010). In experimental hepatotoxicity models in laboratory on higher animals, several herbals exerted hepato-protective/curative effects that warrants their clinical testing. Due to lack of scientific-based pharmacological data, most of the herbal formulations cannot be recommended for the treatment of liver diseases (Stickel and Schuppan, 2007), thus our study detailed on antimicrobial, antioxidant and hepatoprotective activity of S, hirsuta leaf extracts.

Biochemical test like aspartate aminotransferase (AST), alanine aminotransferase (ALT), and alkaline phosphatase (ALP) are commonly measured clinically as a part of a diagnostic evaluation of hepatocellular injury to determine liver health When used in diagnostics, it is always measured in international units/liter (U.L), from the result obtained, the plant extract demonstrated hepatoprotective property at the concentrations employed. This is in correlation with the study of (Wang 2012). The inoculation of bacteria species into the mice caused significan elevation in enzymes level such as AST, ALT and ALP which have been attributed to damaged structural integrity of liver because they are cytoplasmic in location and released into circulation after cellular damages indicating development of hepatotoxicity (Adewale and Olubukola, 2013; Yahya et al. 2013). The amount of these biochemical makers in circulation on analyses gave a predictive level of hepatocellular damages. Evaluated activities of AST and ALT in serum are indicative of cellular leakage and loss function integrity of cell membranes in liver (Rajesh andLatha, 2004). The elevated activities of AST, ALT and ALP are indicative for cellular leakage and loss of functional integrity of the liver cell membrane (Bhadauria, 2012; Shaker et al., 2010) and mitochondrial disruption respectively (Xu et al., 2011). Stabilization activities of the biochemical parameters investigated with treatment by the plant extracts manifested distinct improvement in the functional status of liver cells, which may be due to free radical scavenging action of the extracts. The administration of ethanol leaf extract of $S$. hirsuta has prevented the increase of serum marker enzymes (AST, ALT, ALP) levels which was reflected in hepatoprotective activity. The serum levels of AST, ALT and ALP of the mice returned to almost normal with the healing of hepatic parenchyma and the regeneration of hepatocytes after treatment with ethanol extract. This indicates that on extension of treatment with the extracts, normal architectural structures of liver organ would be retained. This obtained result is in agreement with the results of (Sallie et al., 1991). However, it is of the understanding that the chemical constituents of the extracts has causal role in in vivo prevention of diseases caused by the test bacteria species thus healing the mice from their infections. The biochemical results obtained correlates with the liver histopathology where recovery from injuries was the sustenance by the extracts

Medicinal plants from the tropical and subtropical climates are recognized to possess many medicinal properties. Apart from the commonly consumed vegetables, some under consumed medicinal plants are known in traditional medicine, especially in rural communities of developing countries. These are rarely consumed, unknown, and unfamiliar and have not received much attention as antioxidant sources compared to common vegetables. This could be due to their lack of popularity among local people, lack of scientific information on their nutritional values and lack of promotion or campaigns for these medicinal plants. These medicinal plants are of great importance to consumers considering the biological health benefits they bring and their role as anti aging agents (Subramanion et al., 2012). The present study proves that $S$. hirsuta extracts can be of suitable source for a drug of choice which can resist the toxic effects generated by bacteria in their infections to a considerable extent. It also highlighted that the ethanol extracts could lower down the enzymatic activity thus the architectural structures of liver in the extract treated that was comparable to the control due to healing of sustained injuries during infection. This could be as a result of effective quenching of ROS generated by bacterial infection in the mice. The present study could help as an indicator for the evaluation of different biomarkers of bacterial toxicity on infection and ways out to their possible treatment or prevention.

The mechanisms of microorganisms survive the action of antimicrobial agents have not been well understood and this is making it to remain a non perfect way for a drug of permanent use on bacteria inhibition without discovering side effects. Plants extracts or plants based potential drugs have been of better therapeutic use than synthetically produced drugs. It is of interest in this study the importance of potential plant extracts to control bacteria which have been of threat to human health majorly in rural and urban areas of developing countries where modern medicines are not easily assessed. The findings in this study have scientific information which could serve as an important platform for the development of inexpensive, safe and effective natural medicines for prevention and cure of diseases of bacterial and possibly of non bacterial origins.

\section{CONCLUSION}

This study shows that $S$. hirsuta could be a suitable antibacterial agent against some pathogenic bacteria. Also the result showed that $S$. hirsuta has significant potency on bacterial induced hepatoxicity. The observed antibacterial activity support the traditional use of $S$. hirsuta extract against infectious diseases. In addition the observed hepatoprotective activity of the test plant, suggests that it may contain antioxidant and free radical scavenging properties.

Acknowledgments: Prof. Akindahunsi, A. A., Dr Omoya, F. O and Dr, Olukunle, F. O. are highly appreciated for their advice on this article

\section{REFERENCES}

ADEWALE, A., OLUBUKOLA, S. O. 2013. Hepatoprotective Potential of Some Local Medicinal Plants against 2-Acetylaminoflourene-Induced Damage in Rat. Journal of Toxicology, Article ID 272097, 5 pages http://dx.doi.org/10.1155/2013/272097.

AHMED, L., MOHAMMED, Z., MOHAMMED, F. 1998. Screening of some Indian medicinal plants for their antimicrobial properties. Journal of Ethnopharmacology, 62, 183-193. http://dx.doi.org/10.1016/S00928674(00)81461-0

AJAIYEOBA, E. O., ONOCHA, P. A., NWOSO, S. O., SAMA, W. 2003. Antimicrobial and cytotoxicity evaluation of Buchholzia coriacea stem bark Fitoterapia, 74, 706-709.

AKANJI, M. A., OLAGOKE., O. A., OLOYEDE, O. B. 1993. Effect of chronic consumption of metabisulphite on the integrity of rat livercellular system Toxicology, 81, 273-179. http://dx.doi.org/ 10.1016/0300-483X(93)90010-P

BERGMEYER, H. U., HORDER M., REJ, R. 1986a. International Federation of Clinical Chemistry (IFCC) Scientific Committee, Analytical Section: Approved recommendation (1986) on IFCC methods for the measurement of catalytic concentration of enzymes. Part 2. IFCC method for aspartate aminotransferase (L-aspartate: 2- oxoglutarate aminotransferase, EC 2.6 1:1.), J. Clin. Chem. Clin. Biochem, 24, 497-510.

BERGMEYER, H. U., HORDER, M., REJ, R. 1986b. International Federation of Clinical Chemistry (IFCC) Scientific Committee, Analytical Section: Approved recommendation (1985) on IFCC methods for the measurement of catalytic concentration of enzymes. Part 3. IFCC method for alanine aminotransferase (L-alanine: 2-oxoglutarate aminotransferase, EC 2.6 1:2.), Journal of Clinical Chemical and Clinical Biochemistry, 24, 481-495.

BHADAURIA, M. 2012. Propolis prevents hepatorenal injury induced by chronic exposure to carbon tetrachloride, Evidence in Complementary and Alternative. Medicine, http://dx.doi.org/10.1155/2012/235358

BURKILL, H. M. 1994. The Useful Plants of WestTropical Africa (2nd Edition) Royal Botanical Garden, Kew, 2, 21-25. http://dx.doi.org/10.1520/D6751-12.

CRAGG, G. M ., NEWMAN D, . J. 2001. Medicinals for the millennia. Annals of the New York Academy of Sciences; 953:3-25.

CHATTOPADHYAY, D., MAITI, K., KUNDU, A. P., CHAKRABORTY, M.. S., BHADRA, R., MAUDAL, S. C., MAUDAL, A. B. 2001. Antibacterial activity of Alstonia macrophylla: A folklore of bay islands, Journal of Eth Natural Products and Resources nopharmacology, 77, 49-55.

CHEESBROUGH, M. 2003. Medical laboratory manual: Tropical Health Technology, Doddington publisher, Cambridgeshire, England., 20-33.

DENNIS, P. A. 1988. Herbal Medicine among the Miskito of Eastern Nicaragua. Economic Botany, 42, 16-28

HOLT, J. G., KRIEG, N. R., SNEATH, P. H. A., STANLEY, J. T., WILLIAMS, S. T. 1994. Bergey's manual of determinative bacteriology, 9th edn. Williams and Wilkins, Baltimore, $783 \mathrm{p}$

GAUTHAMAN, K. 2010. Hepatoprotective Herbs - A Review, International Journal of Research in Pharmaceutical.Science, 1, 1-5

KARSHA, V. P., LAKSHMI, O. B. 2010. Antibacterial activity of black pepper (piper nigrum Lin) with special reference to its mode of action on bacteria, Indian Journal of Natural Products and Resources, 1, 213-215 
KHAN, R., ISLAM, B., AKRAM, M., SHAKIL, S., AHMAD, A., Ali, S. M., SIDDIQUI, M., KHAN, A. U. 2009. Antimicrobial activity of five herbal extracts against Multi Drug Resistant (MDR) strains of bacteria and fungus of clinical origin. Molecules, 14, 586-597.

MONKHEANG, P., SUDMOON, T., TANEE, K., NOIKOTR, A., BLETTER, A., CHAVEERACH., A. 2011. Species diversity, usages, molecular markers and barcode of medicinal Senna species (Fabaceae, Caesalpinioideae) in Thailand, Journal of Medicinal Plants Research, 5, 6173 -6181

LOGANAYAKI, N., MANIAN, S. 2010. "In vitro antioxidant properties of indigenous underutilized fruits," Food Science and Biotechnology, 9, 725-734 MOHAMED SALEEM, T. S., MADHUSUDHANA CHETTY, C., RAMKANTH, S., RAJAN, V. S. T., MAHESH KUMAR, K.,. RAJESH, M. G., LATHA, M. S. 2004. Preliminary evaluation of the antihepatotoxic effect of Kamilari, a polyherbal formulation. Journal of Ethnopharmacology, 91, 99-104. NAGMOTI, D. M.,KHATRi, D. K ..JUVEKAR, P. R., JUVEKAR, A. R. 2011 "Antioxidant activity and free radical-scavenging potential of Pithecellobium dulce Benth seed extracts," Free Radical and Antioxidants, 2(2), pp. 37-43. http://dx.doi.org/10.5530/ax.2012.2.2.7

SALLIE, R., TREDGER, J. M., WILLIAM, R. 1991. Drugs and the liver. Part I. Testing liver function, Biopharm Drug Disp, 12, 251-259.

SHAKER, E., MAHMOUD H, MNAA, S. 2010. Sylimarin, the antioxidant component and Silybum marianum extracts prevent liver damage. Food Chemistry and Toxicology, 48,, $803 \quad-\quad 806$. http://dx.doi.org/doi: 10.1016/j.fct.2009.12.011

STICKEL, F., SCHUPPAN, D. 2007. Herbal medicine in the treat-ment of liver diseases, Digestive and Liver Disease, 39, 293-304.

SUBRAMANION, JOTHY,. L., AZLAN AZIZ., YENG, CHEN, 2012.

Sreenivasan Sasidharan, Antioxidant Activity and Hepatoprotective Potential of Polyalthia longifolia and Cassia spectabilis Leaves against Paracetamol-Induced Liver Injury) Evidence-Based Complementary and Alternative Medicine, Article ID 561284, 10 pages. http://dx.doi.org/10.1155//2012/561284

TIWARI, A. K. 2001. Imbalance in anti-oxidant defense and human diseases: Multiple approach of natural anti-oxidants therapy, Curr. Sci. (India); 81 (9):1179-87.

WANG, C. S. 2012. "Impact of increasing alanine aminotransferase levels within normal range on incident diabetes". Journal of Formos Medical Association, 111(4), 201-8.

XU, L., GAO, J., WANG, Y., YU., W., ZHAO, X., YANG, X., ZHONG, Z., QIAN, Z. M. 2011. Myrica rubra extracts protect the liver from CCl4-induced damage, Evidence. Complementary and Alternative Medicine, http://dx.doi. org/10.1093/ ecam/nep196

YAHYA, F., S. S. MAMAT, S. S., KAMAROIZAMAN, M. F. F., A. A SEYEDAN, A. A., JAKIUS, K. F., MAHMOOD, N. D., SHAHRIL, M. S., SUHAILI, Z., N. MOHTARRUDIN, N., SUSANTI, D., SOMCHIT, M. N., TEH, L. K., SALLEH, M. Z and Z. A. ZAKARIA, Z. A. 2013. Hepatoprotective Activity of Methanolic Extract of Bauhinia purpurea Leaves against Paracetamol-Induced Hepatic Damage in Rats. Evidence-Based Complementary and Alternative Medicine, Article ID 636580, 10 pages http://dx.doi.org/10.1155/2013/636580 